\title{
ОБ ОЦЕНКЕ ЭФФЕКТИВНОСТИ ИНСТРУМЕНТОВ КОНТРОЛЯ КАЧЕСТВА ДЕЯТЕЛЬНОСТИ ПРОФЕССОРСКО-ПРЕПОДАВАТЕЛЬСКОГО СОСТАВА В ВЫСШИХ УЧЕБНЫХ ЗАВЕДЕНИЯХ
}

\author{
(c) 2019 Агибалова Елена Леонидовна \\ кандидат филосовских наук, доцент, заведующая кафедрой иностранных языков № 3 \\ Российский экономический университет имени Г.В. Плеханова, Россия, Москва \\ Email: kafedra-iy3@rea.ru
}

(c) 2019 Каржанова Наталья Викторовна

кандидат филосовских наук, доцент кафедры иностранных языков № 3

Российский экономический университет имени Г.В. Плеханова, Россия, Москва

Email:kafmkk@mail.ru

(c) 2019 Забазнова Наталья Михайловна

старший преподаватель кафедры иностранных языков № 3

Российский экономический университет имени Г.В. Плеханова, Россия, Москва

Email:nmzabaznova@gmail.com

(c) 2019 Мурадова Ирина Юрьевна

старший преподаватель кафедры иностранных языков № 3

Российский экономический университет имени Г.В. Плеханова, Россия, Москва

Email:gryad@mail.ru

В статье авторов рассмотрен вопрос об оценке эффективности инструментов контроля качества профессорско-преподавательского состава в высших учебных заведениях. Объектом исследования выступили инструменты контроля качества деятельности профессорско-преподавательского состава в высших учебных заведениях, а предметом - эффективность их применения, измеренная на основе процедуры оценки. Теоретическое и методологическое значения исследования заключены в развитии теории управления человеческими ресурсами в аспекте качества их деятельности. Практическое значение исследования определяется расширением систематизации применения инструментов контроля качества деятельности профессорско-преподавательского состава в высших учебных заведениях.

Ключевые слова: оценка, эффективность, инструменты, контроль, качество деятельности, профессорско-преподавательский состав, высшее учебное заведение.

Функции контроля [6, с. 57] в любой экономической системе априори являлись превалирующими при формировании целостной структуры ее функционирования. Так, согласно мировой статистике $[9$, с. 458$]$ в среднем более $55 \%$ времени работы экономической системы приходится на выполнение контрольно-ревизионных мероприятий [11].

Проявление контроля в большинстве случаев формализуется посредствам применения комплекса разноплановых инструментов, совокупность которых позволяет отслеживать различные показатели функционирования экономических систем либо по целевым установкам (например, методика ключевых показателей эффективности - KРI) [7, с. 11] либо по интер- вальным и саморегулируемым пространствам (например, методика управления по бизнес единицам - Business Unit Management) [8, c. 270].

За последние десять лет [10], ввиду возросшей в процессе осуществления контроля, роли информационной составляющей $[1,4,5]$ количество инструментов, посредствам которых происходит регулирование экономических систем выросло на порядок, при этом совокупный уровень их эффективности снизился. Наиболее значительные темпы снижения эффективности применения инструментов контроля в 20092018 годах имели место в таких сферах, как образование (относительный уровень снижения составил 19,29\%), здравоохранение (относительный уровень снижения составил $16,15 \%$ ) и тяже- 
лая промышленность (относительный уровень снижения составил 12,39\%) [10].

Останавливаясь на образовательной сфере [5, с. 93], как лидере указанного перечня, следует отметить, что большая часть негативных изменений там приходилась на высшее профессиональное образование [3, с. 87], представленное на рынке Российской Федерации совокупностью высших учебных заведений. Отметим, что подавляющая часть объема функций контроля (в совокупности порядка 73,68\% из 100\%) в высших учебных заведениях Российской Федерации в 2009-2018 годах сводилась к анализу качества деятельности профессорскопреподавательского состава. Было выяснено, что по состоянию на начало 2019 года в высших учебных заведениях Российской Федерации [2, с. 63] применялись более ста различных инструментов контроля качества деятельности профессорско-преподавательского состава.

В целях раскрытия темы были собраны и проанализированы усреднённые данные по эффективности применения обозначенной совокупности инструментов контроля в высших учебных заведениях в Российской Федерации. Результаты данной работы приведены на рисунке 1. Посмотрев на рисунок, мы можем увидеть следующее:

- за анализируемый период времени исследуемый уровень данных изменялся относитель- но неравномерно. Существенные, на наш взгляд, пики роста были в 2014 и 2018 годах. В эти периоды средний уровень эффективности применения обозначенных инструментов составил 58,49 и $54,48 \%$ соответственно. Значимые снижения при этом имели место в 2011 (уровень эффективности здесь составил порядка 48,74\%) и 2015 (уровень эффективности здесь составил порядка 50,15\%) годах;

- совокупное изменение по усредненным данным анализируемого показателя эффективности за 2009-2018 годы составило в абсолютном выражении

Основные причины сложившейся ситуации в сфере эффективности применения инструментов контроля качества деятельности профессорско-преподавательского состава в высших учебных заведениях в Российской Федерации по состоянию на начало 2019 года приведены в таблице 1 .

На рис. 2 на основе привлечения группы квалифицированных экспертов отражены результаты ранжирования причин сложившейся ситуации в сфере эффективности применения инструментов контроля качества деятельности профессорско-преподавательского состава в высших учебных заведениях в Российской Федерации по состоянию на начало 2019 года. Данные рисунка 2 свидетельствуют о следующем: наибольшее влияние на анализируемый резуль-

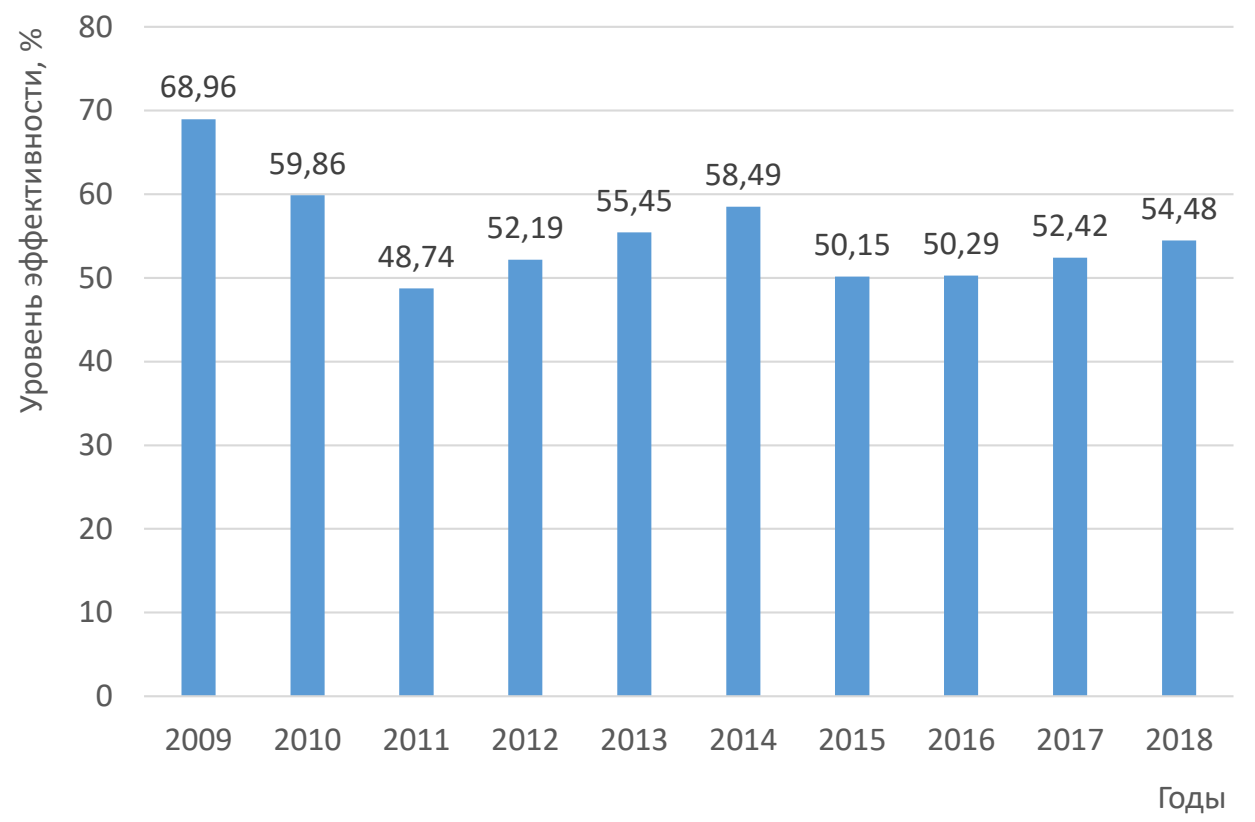

Puc. 1. Усреднённые данные по эффективности применения совокупности инструментов контроля качества деятельности профессорско-преподавательского состава в высших учебных заведениях в Российской Федерации за 2009-2018 годы 
Таблица 1. Основные причины сложившейся ситуации в сфере эффективности применения инструментов контроля качества деятельности профессорско-преподавательского состава в высших учебных заведениях в Российской Федерации по состоянию на начало 2019 года

\begin{tabular}{|c|c|c|}
\hline Причина & Содержание & Дополнение \\
\hline $\begin{array}{l}\text { Активное применение зару- } \\
\text { бежных недостаточно адапти- } \\
\text { рованных инструментов }\end{array}$ & $\begin{array}{l}\text { В процессе анализа персонала многих } \\
\text { высших учебных заведений в послед- } \\
\text { нее время в Российской Федерации } \\
\text { стал активно применяться зарубежный } \\
\text { инструментарий, не прошедший необ- } \\
\text { ходимой адаптации }\end{array}$ & $\begin{array}{l}\text { Достаточно много проблем здесь } \\
\text { имеют место, например, при } \\
\text { использовании международных } \\
\text { индексов цитирования }\end{array}$ \\
\hline $\begin{array}{l}\text { Совместное применение } \\
\text { разноплановых инструментов }\end{array}$ & $\begin{array}{l}\text { Многие аналитики в процессе анализа } \\
\text { высших учебных заведений пытаются } \\
\text { применить сразу несколько разнопла- } \\
\text { новых инструментов, не имея при этом } \\
\text { интегрального параметра интерпрета- } \\
\text { ции их результатов }\end{array}$ & $\begin{array}{l}\text { Нами были изучены ряд примеров, } \\
\text { в которых имело место одновре- } \\
\text { менное применение более десяти } \\
\text { инструментов контроля }\end{array}$ \\
\hline $\begin{array}{l}\text { Необоснованные акценты на } \\
\text { применение недостаточно } \\
\text { эффективных инструментов }\end{array}$ & $\begin{array}{l}\text { Во многих высших учебных заведениях } \\
\text { в Российской Федерации, к сожалению, } \\
\text { имеют место директивные принципы } \\
\text { применения определенных инструмен- } \\
\text { тов контроля качества }\end{array}$ & $\begin{array}{l}\text { Указанные проблемы, зачастую, } \\
\text { имеют место в Российской Федера- } \\
\text { ции на периферии }\end{array}$ \\
\hline
\end{tabular}

Необоснованные акценты на применение недостаточно эффективных инструментов

Совместное применение разноплановых инструментов

Активное применение зарубежных недостаточно адаптированных инструментов

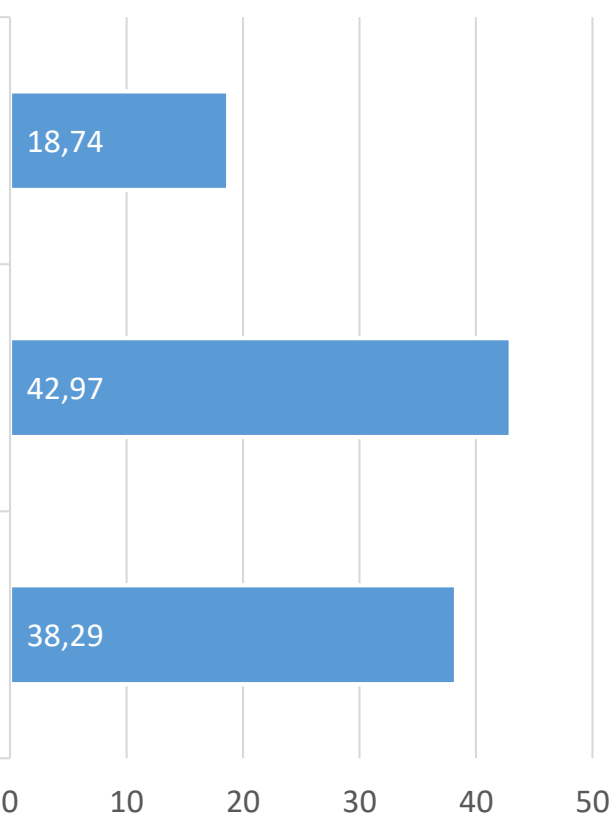

Puc. 2. Результаты ранжирования причин сложившейся ситуации в сфере эффективности применения инструментов контроля качества деятельности профессорско-преподавательского состава в высших учебных заведениях в Российской Федерации по состоянию на начало 2019 года 
тат оказывает совместное применение разноплановых инструментов (ранг 42,97\% из 100); второй по значимости является причина, связанная с активным применением зарубежных недостаточно адаптированных инструментов (ранг 38,29\% из 100); наименее значимая из рассмотренных причин включает необоснованные акценты на применение недостаточно эффективных инструментов (ранг 18,74\% из 100).

Таким образом, можно сделать вывод, что в высших учебных заведениях Российской Федерации процесс оценки эффективности инструментов контроля качества деятельности профессорско-преподавательского состава требует значительной оптимизации, направленной, в частности, на:

- модернизацию совместного применения разноплановых инструментов, включающую внедрение интегрального параметра интерпретации их результатов (оптимальным вариантом здесь будет являться применение специализированных программных продуктов со встроенный нейросетевым алгоритмом);

- адаптацию зарубежного инструментария контроля качества деятельности профессорскопреподавательского состава высших учебных заведений (здесь целесообразнее всего использовать алгоритм комплексной адаптации со специально проработанной методологией);

- нивелирование необоснованных акцентов в применении недостаточно эффективных инструментов (эффективное достижение обозначенного тезиса возможно за счет применения саморегулируемых показателей эффективности процессов).

\section{Библиографический список}

1. Легконогих А. Н., Сорочкина О.Ю. и другие. Оценка качества образовательных услуг с использованием компьютерных технологий / А.Н. Легконогих, О.Ю. Сорочкина, К.В. Киримова, М.В. Рощина, В.С. Катаев // Человеческий капитал - Москва: Изд-во ООО «Объединенная редакция», 2019. - № 10.- С. 88-94.

2. Николаева Е.А., Григорьева И.В. и др. К аспектам влияния оценки эффективности деятельности профессорскопреподавательского состава высшего учебного заведения на укрепление экономической безопасности Российской Федерации / Е.А. Николаева, И.В. Григорьева, И.С. Казимирова, Е.И. Соколова // Экономические науки - Москва: Изд-во ООО «24-Принт», 2019. - № 3.- С. 62-67.

3. Николаева Е. А., Кузнецова Ю.А. и др. Инструменты реализации стратегических инициатив высшего учебного заведения в целях повышения качества образовательного процесса / Е.А. Николаева, Ю.А. Кузнецова, Е.Л. Агибалова, Н.В. Каржанова // Экономические науки - Москва: Изд-во ООО «24-Принт», 2018. - № 9.C. 87-90.

4. Солоницын В.А. Компетентностный подход и система обеспечения качества образования в вузе (на примере московского Университета имени С.Ю. Витте) / В.А. Солоницын // Вестник Московского университета имени С.Ю. Витте. Серия 3: Педагогика. Психология. Образовательные ресурсы и технологии - Москва: Изд-во Московского университета, 2013.- № 1.- С. 12-18.

5. Строганов И. А., Забазнова Н.М. и др. Экономика предпринимательства в высшем учебном заведении: особенности российского подхода / И.А. Строганов, Н.М. Забазнова, И.Ю. Мурадова // Экономические науки Москва: Изд-во ООО «24-Принт», 2018. - № 9.-С. 91-95.

6. Томилин А.К. Внутренний контроль качества образования в вузе / А.К. Томилин // Инженерное образование - Москва: Ассоциация инженерного образования России, 2012.- № 9. - С. 56-61.

7. Angappapillai, A. B., \& Annapoorani, C.K. (2012). «Quality in higher education: An empirical investigation». Afro Asian Journal of Social Sciences, 3 (3.4), pp. 1-11.

8. Öztaş, A., Özdemir, M., \& Mart, C.T. (2017). «Perspectives on quality assurance in higher education in Iraq: A case study at Ishik University». International Journal of Academic Research in Business and Social Sciences, 7 (9), pp. 268-272.

9. Wilkoszewski, H. and E. Sundby (2016), «From Hard to Soft Governance in Multi-level Education Systems». European Journal of Education, Vol. 1, No. 4, pp. 447-461.

10. Рейтинговое агентство «Эксперт РА» [Электронный ресурс]: аналитические материалы - Официальный сайт рейтингового агентства «Эксперт РА», 2019.- Режим доступа: https://raexpert.ru

11. Компания «PricewaterhouseCoopers» [Электронный ресурс]: аналитические материалы - Официальный сайт компании «PricewaterhouseCoopers», 2019.- Режим доступа: https://www.pwc.ru 